\title{
Perception of Nursing students about importance of educational needs and its relation to academic achievement.
}

\author{
Ebtsam Ahmed Mohamed, Refaat Raouf Sadek, Hala Ramzy Yousef \& Nahed Shawkat Abo EL-Magd. \\ Assistant lecturer of Nursing Administration, Faculty of Nursing, Minia University, Egypt. \\ Professor of Public Health, Faculty of Medicine, Minia University, Egypt. \\ Assistant Professor of Nursing Administration, Faculty of Nursing, Assiut University, Egypt. \\ Lecturer of Nursing Administration, Faculty of Nursing -Assiut University, Egypt.
}

\begin{abstract}
Aim of this study: was to examine the perception of nursing students about importance of educational needs and its relation to academic achievement. Methodology: A descriptive correlational design was used for this study. Setting: The present study was conducted at nursing faculty in Minia University. Subject: The present study included a total coverage sample includes all four academic years nursing students during academic year (20122013). Total number of students was $(n=727)$. Tools of the study: $\mathbf{1}^{\text {st }}$ tool was demographic data sheet, $\mathbf{2}^{\text {nd }}$ tool was Nursing Education Importance Instrument (NEII) developed by Schorpp, (2008), and $\mathbf{3}^{\text {rd }}$ tool was student academic achievement. Results: This study revealed that, there was a highly statistical significant differences among the four academic years nursing students as all fourth year nursing students had reported that the educational needs is very important. Conclusions: there was a highly statistical significant difference between perception of the four academic years nursing students about importance of educational needs and academic achievement (favoring to the students had excellent, and followed very good grade). Recommendations: Ask authoritative persons to improve educational environment through providing more space, and educational resources for conducting teaching learning process.
\end{abstract}

\section{Key Words: Nursing Student, Educational Needs \& Academic Achievement.}

\section{Introduction}

Nursing education has the task of preparing students to face challenging and ever changing roles in health care. "In a context of change, nursing education has a major role in ensuring that nursing practice is sensitive, relevant and capable of responding to the wide range of health and social needs (Schorpp, 2008).

The same author stated that to meet importance of educational needs for nursing students requires collaboration among teachers and learner. Therefore, in order to have a collaborative environment, there should be an ongoing evaluation of goals among nursing administration, faculty and students. Documentation of students' perception of their needs and satisfaction with the educational experience will contribute to a comprehensive evaluation of the nursing educational environment.

The measurement of student achievement is important to the function of colleges and universities (Schutz, 2007). Student or graduate success is reflected by the ability to think critically, with selfconfidence, and with the ability to demonstrate ability in the applied setting of work (Grubb, 2006). Lave \& Love, (2005)added that success is determined by the ability to perform competently, whether in the nature of socialization, directed hands on application of tasks, or in the realm of interaction (e.g. team work)

Applying Abraham Maslow's hierarchy of needs theory $(1954,1970)$ provided a conceptual framework for this study. Maslows theory is based on the internal drive of individuals to attain certain goals that are determined by an individual's needs. Maslows organized this concept into a hierarchy of needs. The basic physiological or first level needs. The second level needs personal safety and security, and the third level needs are those in which people need to experience love and belonging (social affiliation). Self-esteem needs follow at the fourth level, and the highest or fifth level need is selfactualization to education is an ideal way to assess lesson plans, courses and educational programs (Hanson, 2012)

\section{Aim of the study}

The current study aimed to examine the perception of nursing students about importance of educational needs and its relation to academic achievement. 


\section{Subject and Method}

\section{Research design}

A descriptive correlational research design was utilized in the present study.

\section{Setting}

The present study was conducted at nursing faculty in Minia University.

\section{Subject}

Subject of the present study included a total coverage sample includes all four academic years nursing students at Faculty of Nursing in Minia University during academic years (2012-2013). Total number of students was (727) .The distributions of the four academic years were: First year (167), second year (203), third year (215) and fourth year (142).

\section{Tools of the study}

The study tool consisted of three parts:

- Demographic data sheet to get information about nursing students at Minia University (name, gender, age, and academic years).

- Nursing Education Importance Instrument (NEII) developed by Schorpp (2008) used to measure study subjects perception toward importance of educational needs, the five subscales related to the five levels in Maslows hierarchy of needs theory (1954, 1970). It divided into five main categories are: Basic learning Needs (BLN) 10 items, Safety and Security Needs (SSN) 11 items, Belonging to the College Nursing Community Needs (BCNCN) 10 items, Esteem Needs (EN) 11 items, and Self Actualization Needs (SAN) 11 items.

\section{Scoring system}

This part were rated on a 4-point likert scale from (scored 1) not at all important, to (scored 2) somewhat important, to (scored 3) moderately important, to (scored 4) very important. The subjects' response to each of the 53 items was summed to yield total importance scores which could range from 53 to 212.

- Responses to items within each importance subscale were summed to yield five subscale scores. Basic learning Needs (BLN) and Belonging to the College Nursing Community Needs (BCNCN) subscale scores ranged from 10 to 40 . Subscale scores for Safety and Security Needs (SSN), Esteem Needs (EN), and Self Actualization Needs (SAN) ranged from 11 to 44 . Because the subscales differ in their number of items, raw subscale scores could not be compared directly. Therefore, subscale mean scores were computed by dividing raw subscale scores by the number of items in each subscale. Mean subscale scores ranged from 1.00 to 4.00 .
Student academic achievement: It includes the final students score was taken at the end of each year, through Grade Point Average (GPA) that included:

Excellent grade means (85\% or more), very good grade means $(75 \%$ less than $85 \%$ ), good grade means (65\% less than $75 \%$ ), satisfactory grade means $(60 \%$ less than 65\%), and fail grade means (60\%).

\section{Pilot study}

A pilot study was conducted for $10 \%$ of the total samples from faculty of nursing students at Minia University. Hence, as no changes in the study sheet or obstacles in understanding the questions, the pilot study subject included in the main study sample. Reliability of nursing education importance instrument is measured by a cronbach's alpha statistical method. Reliabilities about importance of educational needs were $(95,38)$.

\section{Procedures}

An official permission was taken from the (Dean) of nursing faculty in Minia university to collect the necessary data. Written informed consent was taken from the participating students after explaining the aim of the study and they were assured about the confidentiality and privacy of the data. A structured interview with nursing students in Minia University was done to complete questionnaire and make sure of the responses and check that all items were answered. It took about (20-30minute). Data collection and tabulation took a period of six months, from April to September (2013).

Statistical analysis

Data were analyzed using the statistical package for social science (SPSS) version (17), numerical data were expressed as (numbers and percentages, mean and SD), comparison between two variables was done using t-test; ANOVA test and chi-square test were also used. Significant is considered at $(p<0.05)$. 
Results

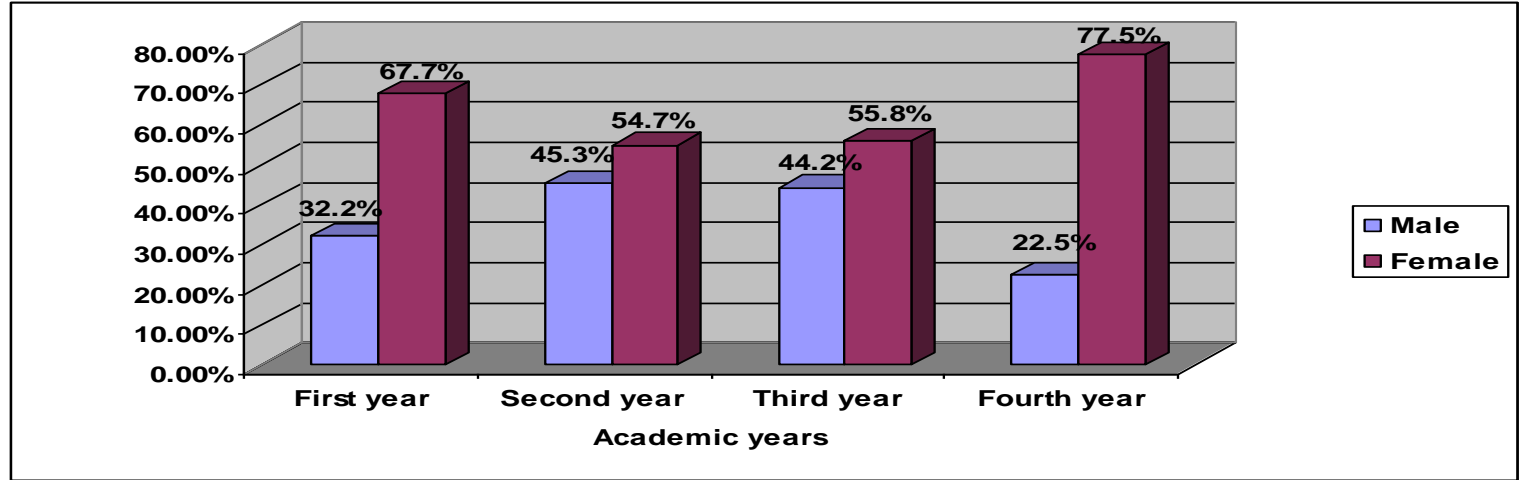

Total $n:($ Male $=273)($ Female $=454)$

Figure (1): Distribution of the nursing students according to gender at the four academic years (total n=727).

Table (1): Frequency distribution of importance of educational needs as perceived by the undergraduate nursing students among the four academic years.

\begin{tabular}{|c|c|c|c|c|c|c|c|c|c|c|c|c|}
\hline \multirow[t]{2}{*}{$\begin{array}{c}\text { Academic years } \\
\text { Importance of } \\
\text { educational needs }\end{array}$} & \multicolumn{2}{|c|}{ First year } & \multicolumn{2}{|c|}{$\begin{array}{l}\text { Second } \\
\text { year }\end{array}$} & \multicolumn{2}{|c|}{$\begin{array}{l}\text { Third } \\
\text { year }\end{array}$} & \multicolumn{2}{|c|}{$\begin{array}{l}\text { Fourth } \\
\text { year }\end{array}$} & \multicolumn{2}{|c|}{ Total } & \multirow[t]{2}{*}{$\mathbf{x}^{2}$} & \multirow[t]{2}{*}{ p } \\
\hline & $\mathbf{N}$ & $\%$ & $\mathbf{N}$ & $\%$ & $\mathbf{N}$ & $\%$ & $\mathbf{N}$ & $\%$ & $\mathbf{N}$ & $\%$ & & \\
\hline $\begin{array}{l}\text { Moderately important } \\
(\mathbf{1 0 6 - 1 5 8 )}\end{array}$ & 26 & 16 & 73 & 36 & 50 & 23 & 0 & 0 & 149 & 20 & \multirow{3}{*}{69.7} & \multirow{3}{*}{0.0001} \\
\hline $\begin{array}{l}\text { Very important } \\
(159-212)\end{array}$ & 140 & 84 & 130 & 64 & 165 & 77 & 142 & 100 & 577 & 80 & & \\
\hline Total & 167 & 100 & 203 & 100 & 215 & 100 & 142 & 100 & 727 & 100 & & \\
\hline
\end{tabular}

N.B (1): Not at all important (1-53), somewhat important (54-105).

N.B (2): None of students reported that the not at all important of educational needs and only one student reported that somewhat important from the first year.

Table (2): Mean scores of perception of the nursing students to the five main elements about importance of educational needs according to academic years.

\begin{tabular}{|c|c|c|c|c|c|}
\hline Importance of educational needs & Academic years & $\mathbf{N}$ & Means \pm SD & $\overline{\mathbf{f}}$ & $\bar{p}$ \\
\hline \multirow{4}{*}{ 1-Basic learning needs. } & First year & 167 & $30.87 \pm 6.84$ & \multirow{4}{*}{77.4} & \multirow{4}{*}{0.0001} \\
\hline & Second year & 203 & $29.34 \pm 7.57$ & & \\
\hline & Third year & 215 & $31.87 \pm 6.96$ & & \\
\hline & Fourth year & 142 & $39.55 \pm 0.95$ & & \\
\hline \multirow{4}{*}{ 2-Safety and security needs } & First year & 167 & $38.05 \pm 6.66$ & \multirow{4}{*}{43.14} & \multirow{4}{*}{0.0001} \\
\hline & Second year & 203 & $37.24 \pm 5.80$ & & \\
\hline & Third year & 215 & $36.76 \pm 7.71$ & & \\
\hline & Fourth year & 142 & $43.69 \pm 0.69$ & & \\
\hline \multirow{4}{*}{$\begin{array}{l}\text { 3- Belonging to the college nursing } \\
\text { community needs }\end{array}$} & First year & 167 & $33.56 \pm 6.43$ & \multirow{4}{*}{68.89} & \multirow{4}{*}{0.0001} \\
\hline & Second year & 203 & $31.97 \pm 6.24$ & & \\
\hline & Third year & 215 & $31.62 \pm 6.26$ & & \\
\hline & Fourth year & 142 & $39.70 \pm 0.84$ & & \\
\hline \multirow{4}{*}{ 4-Esteem needs } & First year & 167 & $38.34 \pm 6.09$ & \multirow{4}{*}{47.28} & \multirow{4}{*}{0.0001} \\
\hline & Second year & 203 & $36.56 \pm 7.79$ & & \\
\hline & Third year & 215 & $36.72 \pm 5.81$ & & \\
\hline & Fourth year & 142 & $43.56 \pm 1.20$ & & \\
\hline
\end{tabular}




\begin{tabular}{|l|c|c|c|c|c|}
\hline Importance of educational needs & Academic years & $\mathbf{N}$ & Means \pm SD & f & p \\
\hline \multirow{3}{*}{ 5-Self-actualization needs } & First year & 167 & $38.35 \pm 6.06$ & & \\
\cline { 2 - 4 } & Second year & 203 & $35.78 \pm 7.39$ & \multirow{3}{*}{66.05} & \multirow{3}{*}{0.0001} \\
\cline { 2 - 4 } & Third year & 215 & $35.79 \pm 6.30$ & \\
\cline { 2 - 4 } & Fourth year & 142 & $43.92 \pm 0.49$ & & \\
\hline
\end{tabular}

Table (3): Mean scores of perception of the nursing students about importance of educational needs according to academic achievement.

\begin{tabular}{|c|c|c|c|c|c|}
\hline \multirow{6}{*}{$\begin{array}{l}\text { Importance of } \\
\text { educational needs }\end{array}$} & Academic achievement & $\mathbf{N}$ & Means \pm SD & $\mathbf{f}$ & p \\
\hline & Fail & 70 & $172.44 \pm 26.42$ & \multirow{5}{*}{6.81} & \multirow{5}{*}{0.0001} \\
\hline & Satisfactory & 119 & $179.46 \pm 23.96$ & & \\
\hline & Good & 102 & $174.15 \pm 27.08$ & & \\
\hline & Very. good & 242 & $183.78 \pm 25.97$ & & \\
\hline & Excellent & 194 & $185.41 \pm 23.87$ & & \\
\hline
\end{tabular}

Table (4): Mean scores of perception of the nursing students to the five main elements about importance of educational needs according to academic achievement.

\begin{tabular}{|c|c|c|c|c|c|}
\hline $\begin{array}{c}\text { Importance of educational } \\
\text { needs }\end{array}$ & $\begin{array}{c}\text { Academic } \\
\text { achievement }\end{array}$ & $\mathbf{N}$ & Means \pm SD & f & $\mathbf{P}$ \\
\hline \multirow{5}{*}{ 1-Basic learning needs. } & Fail & 70 & $31.10 \pm 7.15$ & \multirow{5}{*}{9.19} & \multirow{5}{*}{0.0001} \\
\hline & Satisfactory & 119 & $31.94 \pm 7.15$ & & \\
\hline & Good & 102 & $29.28 \pm 7.98$ & & \\
\hline & Very. good & 242 & $32.87 \pm 7.67$ & & \\
\hline & Excellent & 194 & $34.34 \pm 6.18$ & & \\
\hline \multirow{5}{*}{ 2-Safety and security needs } & Fail & 70 & $36.47 \pm 7.04$ & \multirow{5}{*}{3.62} & \multirow{5}{*}{0.006} \\
\hline & Satisfactory & 119 & $38.34 \pm 6.41$ & & \\
\hline & Good & 102 & $37.41 \pm 6.65$ & & \\
\hline & Very. good & 242 & $39.29 \pm 6.47$ & & \\
\hline & Excellent & 194 & $39.09 \pm 6.58$ & & \\
\hline \multirow{5}{*}{$\begin{array}{l}\text { 3- Belonging to the college } \\
\text { nursing community needs }\end{array}$} & Fail & 70 & $31.26 \pm 7.28$ & \multirow{5}{*}{4.83} & \multirow{5}{*}{0.001} \\
\hline & Satisfactory & 119 & $33.39 \pm 5.97$ & & \\
\hline & Good & 102 & $32.77 \pm 6.40$ & & \\
\hline & Very. good & 242 & $34.59 \pm 6.42$ & & \\
\hline & Excellent & 194 & $34.31 \pm 6.08$ & & \\
\hline \multirow{5}{*}{ 4-Esteem needs } & Fail & 70 & $37.34 \pm 6.76$ & \multirow{5}{*}{1.44} & \multirow{5}{*}{0.217} \\
\hline & Satisfactory & 119 & $38.10 \pm 6.13$ & & \\
\hline & Good & 102 & $37.55 \pm 7.57$ & & \\
\hline & Very. good & 242 & $38.74 \pm 6.43$ & & \\
\hline & Excellent & 194 & $38.94 \pm 6.17$ & & \\
\hline \multirow{5}{*}{ 5-Self-actualization needs } & Fail & 70 & $36.27 \pm 6.90$ & \multirow{5}{*}{2.37} & \multirow{5}{*}{0.05} \\
\hline & Satisfactory & 119 & $37.69 \pm 6.82$ & & \\
\hline & Good & 102 & $37.14 \pm 6.82$ & & \\
\hline & Very. good & 242 & $38.31 \pm 6.68$ & & \\
\hline & Excellent & 194 & $38.74 \pm 6.46$ & & \\
\hline
\end{tabular}


Figure (1): indicated that the high percentage of nursing students were female in all academic years.

Table (1): showed that there was a highly statistical significant differences among the four academic years nursing students as all fourth year nursing students had reported that the educational needs is very important $(\mathrm{P}=0.0001)$.

Table (2): clarified that there was a highly statistical significant differences among the students of the four academic years in relation to perception of the nursing students about importance of educational needs $(\mathrm{P}=0.0001)$. Also in the same table indicated that the fourth year students had the highest mean scores, for the following all main elements, "basic learning needs with mean score $(39.55 \pm 0.95)$, safety and security needs with mean score $(43.69 \pm 0.69)$, belonging to the college nursing community needs with mean score $(39.70 \pm 0.84)$, esteem needs with mean score (43.56 \pm 1.20$)$, and self-actualization needs with mean score $(43.92 \pm 0.49)$ according to perception of the nursing students about importance of educational needs.

As regards to academic achievement, Table (3): showed that there was a highly statistical significant differences among the students of the four academic years in relation to perception of the nursing students about importance of educational needs $(\mathrm{P}=0.0001)$. Also the same table revealed that the students had the highest mean scores in excellent, and followed by the students had a very good grade.

As regards to academic achievement, Table (4): indicated that there was a statistical significant differences among the students of the four academic years favoring to the students had excellent and very good, for the following main elements," basic learning needs $(\mathrm{P}=0.0001)$, safety and security needs $(\mathrm{P}=0.006)$, and belonging to the college nursing community needs $(\mathrm{P}=0.001)$ in relation to perception of the nursing students about importance of educational needs".

\section{Discussion}

Education is a basic right of all people and the basis for a peaceful, healthy and stable world. Also, encourages the development of an individual's total personality, traditional norms and values, and promoting understanding and development of modern science, technology, and environment conservation. Education perpetuates social, economic, and cultural prosperity of human beings and creates an infrastructure for international cooperation through the promotion of mutual understanding and tolerance, thereby enabling the achievement of self-reliant development (Malcolm, 2009).
Maslow developed the hierarchy of needs model in 1940-50's USA, and the hierarchy of needs theory remains valid today for understanding human motivation, management training, and personal development. Indeed, Maslow's ideas surrounding the hierarchy of needs concerning the responsibility of employers to provide a workplace environment that encourages and enables employees to fulfill their own unique potential (self- actualization) are today more relevant than ever (Demus, 2013).

Therefore, this study aimed to examine the perception of nursing students about importance of educational needs, and its relation to academic achievement.

As regard to the present study, the high percentage of nursing students was female in all academic years Figure (1): This results might be due to society view about nursing occupation is appropriate to females more males .This was supported by Walling (2011) who mentioned that while the proportion of men entering the nursing profession has been growing, it remains a female-dominated occupation.

The present study, revealed that the fourth year nursing students had the highest mean scores according to perception of the nursing students about importance of educational needs Table $(\mathbf{1}, \mathbf{2})$ : This result might be due to the fourth year nursing students become mature enough to be able to know what they needs, and which things may benefit them, the fourth year nursing students able to know basic learning needs such as effective and ineffective classroom strategies, safety and security needs such as safe and insecure of educational environment , love needs such as interaction and collaboration between faculty and students, or communicate effectively with others according to their priority and their needs easily, esteem needs such as respect between faculty and student, and self-actualization needs such as clinical sites provide learning opportunities . This was supported by Schorpp (2008) who indicated that a senior nursing student was aware that a knowledgeable faculty and class size are instrumental in their achievement of learning goals.

Also Andrea \& Oconnor (2011) stressed that effective communication focuses on the individual needs and personal takes responsibility for making things happen and achieving results to required standards.

Schorpp, (2008) stated that the nursing students suggested that they feel safe and secure when the educational environment facilitates confidence in the learning process. These findings are supported by the work of Vanhanen \& Janhonen (2000) who suggested that students will achieve self-assurance when educators are sensitive to their individual talents and provide needed guidance with respect. 
Moreover, Gammon \& Morgan-Samuel (2005) stated that increased self-esteem among nursing students contributes to increased coping with stressors associated with attending nursing school and leads to academic achievement.

Rahmani, (2011) asserted that clinical learning environment (CLE) is an important factor in clinical education of nursing students. Clinical education is a fundamental part of nursing education and nursing curriculum. In clinical education, opportunities are given to students to prepare themselves for their future clinical work. The present study revealed that there was a highly statistically significant difference between perceptions of the nursing student's about importance of educational needs and academic achievement in which the nursing students had the high level scores excellent and very good (Table 3, 4). This result might be due to some professional nursing students aware of important of educational needs based on internal motivation which lead students to make decision, and able to success in nursing education, all this will help students to establish a very good and excellent. This result was supported by Perry (2004) who stressed that students' internal motivation used to discover new things and used critical thinking skills to solve problems and success in nursing education.

\section{Conclusion}

In the light of the present findings it was concluded that: the all fourth year nursing students had reported that the educational needs is very important as compared to the first year, second year, and third year. Generally the fourth year nursing students' had the highest mean scores for the following all main elements regarding to their perception about importance of educational needs .Also there was a highly statistical significant differences between perception of the four academic years nursing students about importance of educational needs and academic achievement favoring to the students had excellent, followed by the students had very. good grade

\section{Recommendations}

Based on the important findings of the present study, the following recommendations were suggested

1. Ask authoritative persons to improve educational environment through providing more space, and educational resources for conducting teaching learning process.

2. Apply law and rules for faculty members travelling to meet educational process and to increase number of faculty staff members and their assistance to meet students' needs.

3. Provide training for the faculty staff members and their assistance about using of educational technology and innovative teaching strategy.

4. Recommend the faculty staff members at the faculty of nursing to broaden the clinical setting to provide learning opportunities of nursing students.

\section{References}

1. Andrea, N., \& Oconner, E., (2011): Performance \& Development Review. Clinical instruction and evaluation Chapter: 3, 2nd Ed, P. 11, professor of Emeritus of nursing. Western Connecticut University, Danbury, USA

2. Demus, D., (2013): Maslow hierarchy of needs theory. Vector Study | Just Lucid, Theme Lab | Powered Word Press. Available at http://www.blog.presascanarioskingzulu.com/20 10/11/01/mis-perros.../ nacho2 -2/)

3. Gammon, J., \& Morgan- Samuel (2005): A study to ascertain the effect of structured student tutorial support on student stress, self-esteem , and coping .Journal Nurse Education in Practice, $5,161-171$.

4. Grubb, W., (2006): Working in the middle: Strengthening the education and training for the mid skilled laber force .San Francisco: Jossey. Available at http://www.Boss. regoncssa.org/.../Pres3_Leadership_bibliography .docx

5. Hanson, J., (2012): How to Apply Maslow's Hierarchy of Needs to Education. Retrieved from http://www.en.wikipedia .org/wiki/Abraham_Maslow..

6. Lave P., \& Love, A., (2005): Enhancing student learning, intellectual, social, and emotional integration. ASHE- ERIC Higher Education Report No, 4. Washington, Dc: The Geoge Washington University Press.

7. Malcolm, S., (2009): Effective Approaches in Basic Education. Available at http://www.worldbank.org/education/

8. Perry. G., (2004): Critical Thinking and WebBased Education in Maryland Community Colleges: How the Medium Promote Development. Unpublished doctoral dissertation, University of West Virginia, chapter 6, Pp.197. In,

9. Fayz, S., (2013): Critical thinking and clinical judgment skills for baccalaureate nursing students in EL- Minia University. Master thesisFaculty of nursing. Assiut University.

10. Rahmani, A., (2011): Clinical learning environment in viewpoint of nursing students in 
Tabriz University of Medical Sciences. Iranian Journal of nursing and midwifery research, 16(3): 253-256.

11. Schorpp, M., (2008): The relationships among perceived importance of educational needs, satisfaction with the educational experiences and self-actualization of senior baccalaureate nursing students: An application of Maslow's hierarchy of needs theory. PHD thesis, Widener University. Chester. Pennsylvania, USA. Available at http://www.elcu.edu.eg.com.

12. Schutz, G., (2007): The impact of educational experiences on student persistence at six public universities, PHD thesis .Tennessee State University, USA. Available at http://www.elcu.edu.eg.com.

13. Vanhanen, L., \& Janhonen, S., (2000): Factors association with students orientation to nursing. Journal of Advanced Nursing, 31, 1054-1062.

14. Walling, P., (2011): How did Nursing Become a Female Profession Available at http://www.themale-nurse.com/2011/06/how-did-nursing-

become-female.html 